\title{
12 Teachers' autonomy in assessment: Swedish and German teachers between perceptions of fairness and institutional framings
}

\author{
Kathleen Falkenberg and Johanna Ringarp
}

\section{Introduction}

Teachers' autonomy in assessment is framed through the expectations of school policy- and curriculum-makers, formalised in laws and regulations, and lived through interactions with pupils and their parents. Assessing pupils is always a balancing act between those norms, expectations, rules and regulations on the one side, and teachers' beliefs and professional self-conceptualisation on the other (Falkenberg, 2020). Therefore, when focusing on teachers' autonomy in assessment - and the beliefs, routines and practices connected to it - we can learn about different understandings of teachers' professional role in general, and their autonomy in different education systems in particular.

Teachers' autonomy in assessment is especially crucial in tracked school systems like the German one, since grades and certificates are used at various selective moments with repercussions on further education and the future life chances of pupils. However, even in comprehensive school systems with a clear compensatory and inclusive mission like the Swedish one, grades provide condensed information about pupils' achievements and abilities, becoming a sort of 'quick language' (Lundahl and Waldow, 2009). Although classroom assessment is accompanied by central standardised tests in both countries - though to different degrees and stemming from different traditions (Waldow, 2014) - it is still the individual teachers who make final decisions about pupils' school reports. Teachers' autonomy regarding assessment and grading, therefore, plays a vital role in both countries. This is why, in this chapter, we have chosen Sweden and Germany as comparative units.

Sweden's assessment system has been described as an outlier in the Nordic context. The Swedish education system incorporated an American test-based assessment approach early on, while Norway and Denmark, for example, maintained a more continental tradition until the so-called PISA-shock in the early 2000s (Lundahl and Tveit, 2014; Tveit, 2014). Since our aim is to shed light on what could be called Swedish teacher culture regarding assessment using a comparative approach to teachers' beliefs, in our analysis we focus on Sweden as rather atypical compared to other Nordic countries and Germany as a more continental case in terms of assessment traditions. 
By focusing on teachers' beliefs in both countries, we hope to facilitate a deeper understanding of the broader concept of teacher autonomy. Beliefs structure people's perceptions and influence behaviour in highly complex situations, such as classroom assessment. Additionally, beliefs are 'embedded in the broader educational system, and touch upon social, ethical and political characteristics of a country or culture' (Braeken and Blömeke, 2016, p. 733). As our findings show, it is this interplay between institutional framing of assessment and teachers' beliefs that influences how much autonomy teachers are granted and how they make use of it.

In this chapter, we first describe our theoretical point of departure. We then present the twofold main part of the chapter, beginning with a review of the main features of the assessment system in each of the two countries, especially of teachers' role in assessment processes. Second, we use a typology of justice beliefs in order to structure and analyse the empirical data, focusing on teachers' beliefs regarding assessment and professional autonomy. In the last section, we discuss our findings in the light of professional theory approaches, and end with some final reflections.

\section{Teachers as professionals}

Professionals are organised into professional groups which have a relatively high degree of independence, and their own norms and criteria, and their competence in the field is widely accepted (Evetts, 2011, 2013). This traditional definition (see Larson, 1977; Abbott, 1988) has been criticised for not being suitable for welfare state professions such as teaching (Burrage and Torstendahl, 1990; Evetts, 2003). Moreover, due to societal changes and increased specialisation in many occupational areas, the number of professions has increased - a process that is often described as professionalisation or, from a more critical perspective, as credential inflation (Collins, 2011).

In recent times, with the introduction of New Public Management (NPM) into different societal subsystems, market logic has had a major impact on professions. NPM is usually described as a collection of reforms linking certain international administrative trends that entered the public sector in a number of countries during the 1980s and 1990s (Hood, 1991). For professionals, the introduction of NPM has meant that their autonomy has diminished (Stenlås, 2009). In previous research, this change has been explained through the concepts of professionalisation 'from above' and professionalisation 'from within' (Evetts, 2003). According to Evetts, professionalisation 'from above', or organisational professionalism, involves an increase in the standardisation of work on the part of management, while professionalisation 'from within' describes a situation where professionals, through their autonomy and their scope of action, control themselves. She also refers to the latter as occupational professionalism (Evetts, 2003, 2006, 2013).

Teachers' professional status in the countries analysed is, of course, highly influenced by differing education- and teacher-education systems (for more details, see Chapter 13). However, there are also certain similarities. In both Sweden and Germany, the teacher is both a 'street-level bureaucrat' (Lipsky, 2010) - a civil servant of a public organisation who, in his or her professional practice, executes 
political decisions at the local level - and, at the same time, a member of a profession (Fredriksson, 2010). This balancing act, of working as a public official whilst belonging to a profession, has proven to be a challenge for teachers' selfconceptualisation. The reason lies in the relationship between the profession and public sector organisation, since bureaucratic organisations often conflict with the structures of professions (Terhart, 2011). At the same time, teachers in Nordic countries, not least in Sweden, have enlisted the help of the public sector organisation in their process of professionalisation.

In the following sections, we will analyse teachers' role in assessment in Germany and Sweden. Overall, it becomes clear that the standardisation of professional work has had a greater influence in the Swedish educational policy context than in the German. In the German case, we argue that, despite policy changes, occupational professionalism is still much higher.

\section{Institutional framing of assessment in Germany and Sweden}

Assessment is a crucial part of teachers' daily routines in both countries but there are major differences in the institutional framing and regulation of assessment practices between Sweden and Germany.

Since Germany is a federal republic, with 16 more or less different education systems, we restrict our focus in this chapter to the system in North RhineWestphalia (NRW). NRW is a populous federal state in western Germany, with about as many inhabitants as Sweden. In NRW, compulsory schooling starts at the age of six, and children attend a comprehensive primary school for four years. Grading starts at the latest in year 3 and pupils receive school reports with numerical grades (1-6) for each subject at the end of each semester. In year 4, pupils receive - based upon their learning and grades in the first years of schooling - a 'recommendation for further education', stating which secondary school track pupils should apply for. Although this recommendation is not legally binding, parents tend to follow those recommendations, which means that teachers' judgements have a huge influence on pupils' future schooling and life chances. Sorting pupils into different school types is an expressed policy based on the pedagogical idea of homogenisation through ability-grouping into schools with special profiles where (theoretically) the pupils' full potential and needs will be optimally met. Each of the five secondary tracks follows its own curriculum based upon national education standards, and ends with centralised final exams leading to school-leaving certificates that allow for (or exclude from) certain further educational options.

In each educational track, it is mainly teachers who assess pupils' learning achievements based upon their professional experience and the standards defined in the respective curricula. Even the standardised mandatory proficiency tests (Vergleichsarbeiten) in years 3 and 8, which were introduced in 2008, are marked by teachers from the same school. Pupils' work is constantly graded throughout the school year and regularly summed up in school reports which are then used to decide whether pupils move up to the next grade or must repeat the school year. If pupils repeatedly fail to reach a certain grade in the main subjects, teachers and headmasters can advise pupils to leave the school type and continue at a 'lower' 
track (Abschulung). Thus, there are several points of selection in German education systems where teachers' assessments can lead to far-reaching consequences for pupils' lives. Historically speaking, the importance of grades and certificates for further careers has its roots in a hierarchical system where access to societal positions is bound to certain educational certifications and eligibility (Berechtigungswesen; see Zymek, 2008).

The Swedish comprehensive school system has traditionally aimed at democracy and equality under the social-democratic slogan of 'one school for all', but has been challenged more and more by decentralisation and marketisation since the early 1990s. The system today consists of a nine-year grundskola (combining preschool, primary- and lower-secondary education) followed by a three-year gymnasieskola for upper-secondary and vocational education. Grading traditionally started comparatively late: until 2012, pupils were graded for the first time in year 8; nowadays grading starts in year 6 with an ongoing debate about starting grading already in year 4 (Utbildningsdepartementet, 2019). Assessment in the first years focuses mainly on formative feedback and individualised study, with development talks between teachers, pupils and parents every semester. These lead to the formulation of individual development plans (IUP) for every child. In addition to classroom assessment, there is a strong tradition of standardised testing in the Swedish school system (see Waldow, 2014) which is supposed to guarantee equivalent grading throughout the country. In order to apply for one of the national secondary school programmes, pupils need to fulfil certain minimum standards defined in the curriculum. Pupils who do not meet these standards for one or more subjects can still complete their school report through various programmes. There are no final exams, and pupils receive final report cards containing all their course grades at the end of secondary school.

Complementing the regular school system, there is also a system of adult education (Komvux), through which secondary education can be completed at any stage in life. Compared with the selective German system, in the Swedish comprehensive school system, there are far fewer consequences for pupils attached to teachers' grading. But paradoxically, as we will show later, this doesn't reduce pressure on either pupils or teachers.

Looking at the norms and regulations for assessment in both countries, there is a strong normative discourse in Swedish official documents and regulations regarding teacher assessment, focusing on a notion of holistic yet equivalent assessment of pupils' knowledge. Nearly all publications of the Swedish National Agency for Education (Skolverket) regarding assessment stress the importance of equivalent grading throughout the country. What is expected of teachers in assessment and what counts as 'fair' assessment seem far clearer on a normative level in the Swedish case than in the German. On the other hand, Swedish teachers enjoy much more freedom in terms of the actual form and frequency of assessment than their German counterparts. In the NRW curriculum documents, learning goals are defined for every school year, which implies linear knowledge acquisition and leads to pressure on both pupils and teachers to cover all the topics expected to be dealt with during a school year. Additionally, detailed guidelines exist on the number of written tests teachers have to process in a certain subject during a certain timespan, and how much weight these should have relative to oral assessments. This level of detail 
stands in sharp contrast to the generosity of the general service regulations (Dienstordnung) for teachers in NRW, which states that 'it is part of being a teacher to educate, teach, advise and assess pupils on their own responsibility and in pedagogical freedom' (MSW, 2011, section 4(1)).

Although the Swedish regulations do not prescribe specific forms of assessment, the comprehensive school curriculum contains far more grading details than the German. The curriculum contains syllabuses with learning objectives for years 3,6 and 9 , which are then further specified into knowledge requirements for each subject at three different grade levels (A, C and E). Those knowledge requirements express minimum standards that should be achieved by all pupils in order to get a certain grade and are presented as the most important tool for teachers when grading their pupils' work. There are numerous additional publications for each subject explaining how to use the knowledge requirements in assessment practice. At the same time, teachers are encouraged to use all available information about pupils' learning process when assessing them.

It is important to keep in mind that the institutional framing of assessment practices - and thereby teachers' autonomy in assessment - provides precisely that: a framing of practices. How this framing and the embedded room of manoeuvre is used by professionals is still highly contextual and situationally bound.

\section{Teachers' perspective on autonomy in assessment}

The empirical data discussed in this section stem from a comparative research project focusing on teachers' justice beliefs regarding assessment in Germany and Sweden (Falkenberg, 2020). ${ }^{1}$ The analysis draws on three types of data: official documents (e.g., regulations, laws, guides for teachers), 44 interviews with teachers from different school types who teach Maths or German/Swedish in years 7-10 and assessment materials used or produced by teachers. The interviews focused on teachers' understandings of 'fair assessment', their assessment routines and practices, as well as challenges or constraints they faced when trying to reach an assessment that they perceived as fair. The issue of autonomy in assessment came up regularly in all interviews with teachers from both countries - whether as a prerequisite for fair assessment or in terms of a perceived lack of autonomy that prevents a fair assessment. The outcome of the analysis is a typology of four different patterns of teachers' justice beliefs regarding assessment that were found across the entire sample of teachers from both countries: arithmetic, procedural-bureaucratic, discursive-interactive and compensatory justice. Each of these shows how teachers balance different expectations in order to reach a fair assessment by using different assessment strategies. In the following sections, we will discuss these four types of justice beliefs and their country-specific tendencies, with a focus on the issue of professional autonomy in assessment.

\section{Manipulating the numbers: autonomy and the arithmetic justice belief}

The arithmetic justice belief is marked by a self-image as subject teacher, whose main responsibility is to convey subject knowledge and, afterwards, to test pupils' knowledge. Assessment is mainly understood as a measurement using written tests while 
other forms of assessment, for example, oral examinations or group work, are considered less valid. The focus is on summative assessment at the end of a learning unit with no further advice for improving the learning process. The entire assessment process is dominated by arithmetic procedures in which pupils' tested abilities and performances are transformed into points or numbers that are summarised and converted into grades, often by averaging individual grades from different assessment occasions throughout the school year into final grades. Teachers expressing an arithmetic justice belief tend to expect a Gaussian 'normal' distribution of grades in each classroom and tend to use marking schemes with strict grade boundaries that fit this expectation. Pupils then get sorted into the grading scale along this normal distribution, but the teachers' strategy is challenged regularly through unexpected pupil achievement. Especially, the German teachers who hold this kind of justice belief often change marking schemes retrospectively - meaning, after marking all the tests of a learning group - in order to align grades with their expectations of a particular learning group. This manipulation of marking schemes is then legitimised by referring to teachers' 'pedagogical freedom', ${ }^{2}$ stressing that this would be 'way more fair' to the whole learning group. In other words, although those teachers ground their justice belief in arithmetic accuracy, it is their professional room for manoeuvre that enables them to reach a fair assessment even in challenging situations.

The Swedish teachers mostly rejected the idea of assessment as (mainly) assigning points to written tests and grade averages and stated that 'we should assess formatively'. Marking tests and having strict grade boundaries like their German counterparts is considered as summative assessment - which many teachers referred to as something from the past or at least something to be soon overcome.

One way to move away from points and grades dominating communication with pupils about their achievement is the semantic differentiation between 'grades' and 'grade levels'. A Swedish teacher, Pernilla, explained that in her communication with pupils, she uses the term 'grade level' when talking about their learning process during the school year. In her opinion, only when awarding the final grade at the end of the school year should the term 'grade' be used. Otherwise, pupils would be tempted to merely sum up individual grades 'as if they were facts'. Pernilla insisted instead: 'I am looking at all the tasks in the end and then I'll see the progression and the grade they are growing into'. In doing so, Pernilla acts in line with the Skolverket regulation which explicitly states that final grades should not be simple averages of all grades received at a certain time, but instead should be comprehensive and reflect all the information the teacher has about pupils' knowledge (Skolverket, 2012, p. 23).

Nevertheless, some Swedish teachers reported that they do sum up and average all the assessments from one school year, knowingly ignoring the abovementioned regulation.

One explanation for this can be found in an interview with Malin, who stated that pupils get highly confused about the difference between 'grade level' and 'grade'. Malin uses rubrics for her own documentation and as feedback instruments for pupils. These are based on the syllabuses and contain the core content and four columns for notes. Those columns are labelled as follows: level 1 (F), level 
2 (E), level 3 (C) and level 4 (A). It may seem like a minor detail, but by naming the columns in this manner, the teacher herself blurs the semantic distinction between grade level (1-4) and grade $(\mathrm{A}-\mathrm{F})$ while at the same time knowing that 'actually you shouldn't say C about the competences. You should say level because it is only then $\mathrm{C}$ if all [...] is compiled into a grade'.

Although all Swedish teachers denied that their own assessment practice is based on arithmetic procedures - as did several of their German counterparts more self-confidently - traces of those procedures can be found in the analysis. But, in contrast to the German teachers, who lean towards an arithmetic justice belief, the Swedish teachers point to external expectations (like Skolverket regulations, or pupils' complaints about the vagueness of the term 'grade level') to legitimate their assessment practices. German teachers rely instead on the vague but obviously reassuring concept of 'pedagogical freedom', which can be understood as a hint at differing modes of professional autonomy.

\section{Following and bending the rules: autonomy and the procedural-bureaucratic justice belief}

For those holding the procedural-bureaucratic justice belief, an objective, comparable and correct assessment is central. This is achieved through thorough accountability, along with an emphasis on transparency and the need for detailed documentation. In contrast to the discursive-interactive and compensatory justice beliefs discussed later in this chapter, transparency and documentation serve mainly as legal protection strategies in case pupils or parents question teachers' decisions, rather than as ways of reaching a shared understanding or of giving formative feedback. Consequently, these teachers refer often to the legal framework, stressing their status as public servants with professional duties.

However, the need to produce legally safe grades is framed very differently in the two countries: whereas German parents have the right to appeal against individual grades in court, in Sweden, there is no possibility of a judicial appeal process once grades are written down in reports (Waldow, 2014). Nevertheless, Swedish teachers are obliged to make sure that their grades are legally sound, which seems to lead to a growing pressure for documentation. As one teacher, Fredrik put it, he feels the need to 'keep track of EVERY SINGLE STEP right from the beginning', which he does using a digital assessment tool.This tool is based on the core content and knowledge requirements in the syllabuses, which means that Fredrik can 'copy and paste' everything 'easily' into separate files for each pupil. He stressed repeatedly that assessment has become easier, his workload is reduced and that his assessments are somewhat more 'objective' and legally sound. The way he described his assessment practice, though, is reminiscent more of a mechanical sorting process: picking the learning goals, 'results' building up in the programme's registers, 'plopplop-plop', clicking the right grade, colour coding it, 'very easy', 'that's how it goes'. There is virtually no hesitation or doubt in his narrative but a strong emphasis on matching pupils' abilities to the 'right' grade level.

The German Maths teacher Herr Dabert ${ }^{3}$ uses a similar strategy, keeping very detailed documentation in order to be accountable 'at any time' and to secure a 
legally sound assessment. But, in contrast to the Swedish teacher, Fredrik, he confidently admitted that he actively chooses to bypass certain regulations by referring to his 'pedagogical freedom'. A telling example of this is that, although he knows about the rule that homework shouldn't be graded, Herr Dabert includes missing homework, disguised as demerits, in his documentation system, in which he assigns points to each pupil in every lesson, aggregates them and incorporates them into the final grade at the end of the school year. Here, he demonstrates that he knows the rules very well - and also knows how to bend them. The discourse of "pedagogical freedom' helps him as an occupational professional to legitimise deviancies from what he himself states is important for fair assessment: to stay within the legal framework and follow meticulous assessment procedures.

In general, when explaining their assessment practices, Swedish teachers referred far more often to Skolverket publications and positions than their German counterparts to official documents from the NRW Ministry of Education. We argue that this is an example of the increased standardisation of Swedish teachers and teaching. Since digitised assessment systems have become more and more popular in Sweden since data were collected for this study in 2015, future researchers may determine how enhanced digitisation since then has influenced assessment practices and led to an even more standardised approach to assessment.

\section{Deciding together: autonomy and the discursive-interactive justice belief}

The discursive-interactive justice belief is marked by a strong focus on personal relationships and intensive communication between teachers and their pupils as well as between colleagues. While teachers with arithmetic and procedural-bureaucratic justice beliefs try to avoid 'exhausting discussions' with pupils about assessment and grading, those with a discursive-interactive justice belief rest their perception of fairness in exactly these interactions with pupils and the communicative validation of their judgements. Ensuring transparency about assessment criteria by talking through and reaching an agreement about assessment results is a typical strategy for these teachers. They distance themselves sharply from the arithmetic logic, as a German teacher at Hauptschule expressed it: 'And if it happens that a class goes along with [the grade in the school year report] then we have achieved more than if I hide myself away behind some points saying:You have achieved an average of 2.75 and that's grade 3 . That is not ok, I think'. This teacher prefers to discuss her decisions regarding the final grades of individual pupils with the whole learning group. Especially for critical decisions, like giving the same grade to two pupils with differing performances, she stresses her professional autonomy in assessment and uses classroom discussions about individual abilities and learning difficulties in order to make her decisions transparent to the pupils. By opening them up to discussion, she seeks - and gets - legitimation for these grades. The term 'pedagogical freedom' in this justice belief is used in a different sense than in the arithmetic justice belief: here, communicatively produced agreement between teachers and pupils allows for deviations in the common procedure of summing up and averaging grades into a final grade. 
In the Swedish interviews, it emerged that discursive-interactive strategies are mainly used for the interpretation of different knowledge requirements for certain grades. By discussing the detailed syllabuses intensively with colleagues and through collaborative teaching strategies, teachers try to reach a 'shared understanding' of the regulations which, in their opinion, promotes a fair assessment. Even though German syllabuses contain core contents and learning goals just like the Swedish ones, they are lacking in precise assessment criteria resembling the Swedish knowledge requirements. German teachers are freer in defining what exactly pupils need to know - or, better, show - in order to get a certain grade, while the Swedish knowledge requirements, intended by Skolverket to help teachers assess pupils' abilities and performance, instead pose a challenge. The 'translation work' of the official documents takes up much time and mental resources of these teachers since they aim at a deeper understanding of assessment than just giving the same grade (as is the focus of teachers who adhere to a procedural-bureaucratic justice belief).

Interestingly, Swedish teachers tend more often to engage in collegial debates and cooperative teaching than their German colleagues who emphasised instead their idea of assessment being an individual rather than a collective act by talking about 'my criteria', 'my grades' or 'in my opinion'. Younger teachers are an exception, as are those who stated that the introduction of standardised proficiency tests and centralised final exams has led to a greater need for cooperation amongst teachers in terms of grading (see Maag Merki, 2012).

The most important country-specific difference relates to timing: whereas German teachers mostly tend to explain final grades retrospectively after the learning process is finished, Swedish teachers start discussing at the beginning of the learning process with an explanation of knowledge requirements. This can partly be explained by the differing regulations: there are numerous publications from Skolverket expressing the need to explain criteria to pupils, make sure they know where they stand during the learning process and to communicate every little achievement (see, e.g., Skolverket, 2012, pp. 10-11). The downside of this continuous 'achievement talk' is that pupils are fixated on grades rather than the actual learning and knowledge gained, which sometimes leads to performance pressure on pupils (see Vogt, 2017). There are few hints in the German documents that pupils should be informed about their achievements and grades by their teachers but since the actual definition of which performance equals which grade is up to the individual teacher, there is much more freedom for German teachers than for their Swedish colleagues.

Nevertheless, achieving communicative validation of their assessment through discussions with either pupils or colleagues is a common element of all teachers who adhere to a discursive-interactive justice belief.

\section{Finding different ways - autonomy and the compensatory justice belief}

The compensatory justice belief is shaped by a self-image as a 'coach' or 'pedagogue' who feels responsible for pupils' learning processes and the creation of an environment where all pupils can achieve their best. Teachers take responsibility for pupils' learning - and sometimes even the production of learning outcomes - referring to 


\section{Kathleen Falkenberg and Johanna Ringarp}

assessment as an ongoing process that should mainly serve as formative feedback for pupils. Individual support is highlighted as a key instrument for fair assessment and considering effort and individual learning curves instead of focusing only on results. In accordance with this, concepts like objectivity, comparability and measurement are of minor importance, unlike in the arithmetic justice belief. The compensatory justice belief is found in both Sweden and Germany but, with their differing institutional frames, the extent to which teachers can put it into practice differs greatly.

Most differences are found in the organisational adaptations for individual pupils. Under Swedish regulations, all pupils should be enabled to develop and learn as far as possible (SFS, 2010:800, Chapter 3 section 2). This translates into IUPs and extra adaptations or special support as an integral part of teaching and assessment, resulting in greater organisational flexibility for teaching and assessment.

German regulations, on the other hand, also refer to individual support for pupils, but there is little or no room for teachers to adjust assessment processes. The only exception is when pupils have diagnosed special needs that entitle them to extra support or compensatory measures like more time for written tests.

This institutional framing makes it harder for German teachers with a compensatory justice belief to actually live up to their ideals and make use of their professional autonomy in assessment. One exception in the sample is the headteacher of a Realschule, Frau Hollerdieck, who spoke about her supportive and individualfocused assessment practice. Contrary to Sweden, where headteachers are only responsible for managerial issues, German headteachers regularly teach in addition to those other tasks. Throughout the interview, it became clear that Frau Hollerdieck, due to her position as headteacher, has more room for manoeuvre and is able to ignore or suspend certain rules that regular teachers are obliged to follow. She insisted that teachers should use their pedagogical wiggle room 'ALWAYS in favour of the pupil when in doubt' and described how she tries to encourage the teachers of her school to have a stronger focus on individual support. Compared to other teachers in the sample, it is far easier for her as a headteacher to make use of her professional autonomy (and to recommend her staff to use theirs) than it is for regular teachers at schools where other beliefs are dominant. Additionally, working in a tracked school system like the German one often leads to the common belief that tracking pupils into different school types is sufficient to provide them with individual support - which is highly debatable (e.g., Tillmann, 2008).

Most Swedish teachers referred to individualised teaching and learning as common ground, although the intensity varied. Those who expressed a strong compensatory justice belief often stressed that it is their 'mission' to create diverse possibilities where pupils can learn and achieve as much as possible. 'Taking pupils by the hand' or 'showing them the way' were typical metaphors used to express how responsible teachers feel about their pupils' learning outcomes. In general, Swedish teachers with a compensatory justice belief make use of several organisational instruments in order to adjust teaching and assessment to individual pupils: by using different assessment forms, extending the time span during which grades are assigned for certain subjects into the next school year, offering additional 
tutoring, etc. Sometimes, finding different ways even means deviating from Skolverket regulations. But, as one teacher reported, finding different ways can be tricky if pupils do not cooperate.

In short, compensatory justice beliefs are found in interviews from both countries, albeit with different emphases and implications. But, unlike the other three types of justice beliefs, Swedish teachers have much more professional autonomy to realise their ideals than their German colleagues.

\section{Discussion and final reflections}

This chapter demonstrates that teachers' professional autonomy in assessment is highly contextual and teachers' beliefs regarding assessment differ not only between different contexts, but also within educational settings.

However, the interviews also make clear that the German teachers, especially, refer to a so-called 'pedagogical freedom' when talking about their assessment practice. Nevertheless, the way this freedom is used in certain situations differs according to the four justice beliefs: legitimating the manipulation of marking schemes, navigating around and bending regulations, achieving communicative agreement between teachers and pupils, or using it for compensatory purposes. Pedagogical freedom is therefore used to legitimate professional decisions, especially sensitive ones that will probably have severe repercussions on pupils' life chances, such as school year reports. Swedish teachers, on the other hand, refer more often to regulations and to Skolverket as the central actor in assessment-related questions when talking about their assessment practices. Often, they bring their own copy of the curriculum, explaining their assessment practice by reading out the detailed knowledge requirements. We therefore argue that Swedish teachers are far more limited in their professional autonomy regarding assessment than their German colleagues - with an exception being compensatory measurements and individual adjustments in assessment where the institutional framing supports Swedish teachers more than German ones. Linking again to the distinction of professionalisation 'from above' and 'within', we propose that Swedish teachers tend more to organisational professionalism ('from above') whereas German teachers lean towards occupational professionalism ('from within'), in Evetts' (2003, 2006, 2013) understanding. This is in line with other findings about educational governance regimes and teacher autonomy in Sweden and Germany (Wermke, Rick Olason and Salokangas, 2019).

We conclude that teachers in both countries refer to different sources of legitimation when explaining their assessment practices - and that those legitimations are partly framed through institutional settings such as regulations and the school system in general and partly through teachers' own justice beliefs. Although teachers in both countries act as professionals when assigning grades, their degree of autonomy in those decisions is highly influenced by what is possible from an institutional perspective and by what is seen to be fair.

This chapter has not only contributed knowledge about Swedish and German teachers' professional autonomy regarding assessment in school. It has also 


\section{Kathleen Falkenberg and Johanna Ringarp}

contributed to a broader understanding of the concept of teacher autonomy and its local contextuality - which is especially fruitful for the analysis of Nordic teacher cultures.

\section{Notes}

1 This project was part of the Emmy-Noether-research group 'Different worlds of meritocracy? Educational assessment and conceptions of justice in Germany, Sweden and England in the age of "standards-based reform"” (2010-2019) led by Florian Waldow and funded by the German Research Foundation (DFG).

2 Interview extracts are marked by quotation marks.

3 The pseudonyms used in this study reflect an additional difference between German and Swedish teachers: whereas in Sweden and other Nordic countries, it is common to refer to people by their first name - even in professional contexts - German teachers (and other professionals) are addressed using the formal titles Herr/Frau and the person's last name.

\section{References}

Abbott, A.D. (1988) The system of professions: an essay on the division of expert labour. Chicago: University of Chicago Press.

Braeken, J. and Blömeke, S. (2016) 'Comparing future teachers' beliefs across countries: approximate measurement invariance with Bayesian elastic constraints for local item dependence and differential item functioning', Assessment $\&$ Evaluation in Higher Education, 41(5), pp. 733-749. doi: 10.1080/02602938.2016.1161005.

Burrage, M. and Torstendahl, R. (eds.) (1990) The formation of professions: knowledge, state and strategy. London: Sage.

Collins, R. (2011) 'Credential inflation and the future of universities', Italian Journal of the Sociology of Education, 3(2), pp. 228-251.

Evetts, J. (2003) 'The sociological analysis of professionalism: occupational change in the modern world', International Sociology, 18(2), pp. 395-415. doi: 10.1177/ 0268580903018002005.

Evetts, J. (2006) 'Short note: the sociology of professional groups: new directions', Current Sociology, 54(1), pp. 133-143. doi: 10.1177/0011392106057161.

Evetts, J. (2011) 'A new professionalism? Challenges and opportunities', Current Sociology, 59(4), pp. 406-422. doi: 10.1177/0011392111402585.

Evetts, J. (2013) ‘Professionalism: value and ideology', Current Sociology, 61(5-6), pp. 778-796. doi: 10.1177/0011392113479316.

Falkenberg, K. (2020) Gerechtigkeitsüberzeugungen bei der Leistungsbeurteilung. Eine GroundedTheory-Studie mit Lehrkräften im deutsch-schwedischen Vergleich. Wiesbaden: SpringerVS.

Fredriksson, A. (2010) Marknaden och lärarna: hur organiseringen av skolan påverkar lärares offentliga tjänstemannaskap. Göteborg: Göteborgs universitet.

Hood, C. (1991) ‘A public management for all seasons?', Public Administration, 69(1), pp. 3-19. doi: 10.1111/j.1467-9299.1991.tb00779.x.

Larson, M.S. (1977) The rise of professionalism: a sociological analysis. Berkeley: University of California Press.

Lipsky, M. (2010) Street-level bureaucracy: dilemmas of the individual in public services. New York: Russell Sage Foundation.

Lundahl, C. and Tveit, S. (2014) 'Att legitimera nationella prov i Sverige och i Norge - en fråga om profession och tradition', Pedagogisk forskning i Sverige, (4-5), pp. 297-323. 
Lundahl, C. and Waldow, F. (2009) 'Standardisation and "quick languages": the shape-shifting of standardised measurement of pupil achievement in Sweden and Germany', Comparative Education, 45(3), pp. 365-385. doi: 10.1080/03050060903184940.

Maag Merki, K. (2012) Zentralabitur. Die längsschnittliche Analyse der Wirkungen der Einführung zentraler Abiturprüfungen in Deutschland. Wiesbaden: SpringerVS.

Ministerium für Schule und Weiterbildung des Landes Nordrhein-Westfalen (MSW) (2011) Allgemeine Dienstordnung für Lehrerinnen und Lehrer, Schulleiterinnen und Schulleiter an öffentlichen Schulen. Düsseldorf: MSW.

Skolverket (2012) Bedömning och betygssättning i gymnasieskolan (Allmänna råd). Stockholm.

Stenlås, N. (2009) En kår $i$ kläm: läraryrket mellan professionella ideal och statliga reformideologier. Stockholm: Regeringskansliet.

SFS, 2010:800. Skollag, Swedish Government Act, 2010:800, Education Act.

Terhart, E. (2011) 'Lehrerberuf und Professionalität: Gewandeltes Begriffsverständnis - neue Herausforderungen', in Helsper, W. and Tippelt, R. (eds.), Pädagogische Professionalität (57. Beiheft der Zeitschrift für Pädagogik). Weinheim: Beltz, pp. 202-224.

Tillmann, K.-J. (2008) 'Die homogene Lerngruppe - oder: System jagt Fiktion', in Otto, H.-U. and Rauschenbach, T. (eds.), Die andere Seite der Bildung. Wiesbaden: Springer Vorschau, pp. 33-39.

Tveit, S. (2014) 'Educational assessment in Norway', Assessment in Education: Principles, Policy E Practice, 21(2), pp. 221-237. doi: 10.1080/0969594X.2013.830079.

Utbildningsdepartementet (2019) Möjlighet till betyg från årskurs 4 (Promemoria, U2019/04190/S). Available at: https://www.regeringen.se/rattsliga-dokument/departementsserien-och-promemorior/2019/12/mojlighet-till-betyg-fran-arskurs-4/ (Accessed: 13 May 2021).

Vogt, B. (2017) Just assessment in school: pupils' conceptions in Sweden and Germany. Växjö: Linnéuniversitet.

Waldow, F. (2014) 'Conceptions of justice in the examination systems of England, Germany, and Sweden: a look at safeguards of fair procedure and possibilities of appeal', Comparative Education Review, 58(2), pp. 322-343. doi: 10.1086/674781.

Wermke, W., Rick Olason, S. and Salokangas, M. (2019) 'Decision-making and control: perceived autonomy of teachers in Germany and Sweden', Journal of Curriculum Studies, 51(3), pp. 306-325. doi: 10.1080/00220272.2018.1482960.

Zymek, B. (2008) 'Geschichte des Schulwesens und des Lehrerberufs', in Helsper, W. and Böhme, J. (eds.), Handbuch der Schulforschung (2nd ed.). Wiesbaden: Springer Vorschau, pp. 203-237. doi: 10.1007/978-3-531-91095-6_8. 